\title{
Leopold H. Haimson, 1927-2010
}

Leopold Haimson, professor emeritus of history at Columbia University, died at his home in New York City on 18 December 2010; he was 83 years old. A leading historian of late imperial and early Soviet history, Haimson shaped the field as a scholar, as a mentor to several generations of graduate students, and as a pioneer in collaborative scholarship with historians from Europe, Russia, and North America. In 2009 the American Association for the Advancement of Slavic Studies (AAASS) recognized these contributions with their award for Distinguished Contributions to Slavic Studies.

Haimson was born in Brussels in 1927, the son of Russian émigrés who had settled in Belgium after the revolution. In 1940, the family fled the Nazi invasion by fishing boat to Normandy, a voyage that brought them dangerously near to the Allied evacuation at Dunkirk; they ultimately found refuge in the United States. In 1943, Haimson gained admission to Harvard University, having lied about his age, as he later admitted. He came late to the study of Russian history, abandoning an earlier interest in the French Revolution. Impressed by the role of the Red Army in the defeat of Nazi Germany, Haimson began studying Russian in 1945 and embarked on his graduate training at Harvard in 1946 as a member of the famous "Karpovich seminar."

At Harvard, Haimson studied with a now legendary cohort of fellow Russianists that included Richard Pipes, Martin Malia, and Marc Raeff, later his Columbia colleague. However, he spent most of his graduate years in New York, where he worked with the anthropologist Margaret Mead on a project investigating Soviet political culture. This experience proved influential in his subsequent work. Haimson earned his doctorate from Harvard in 1952, the first step on a cursus honorum that took him in 1956 to his first position at the University of Chicago, followed nine years later by his move to Columbia University, where he taught for the next three decades. He also enjoyed a long-standing association with the Maison des sciences de l'homme in Paris, where he worked closely with Fernand Braudel, one of the Annalistes who also influenced Haimson's own approach to historical method.

In 1955, Harvard University Press published Haimson's first book, The Russian Marxists and the Origins of Bolshevism, a work of enduring importance that situated Russian Marxism in the psychological and intellectual contexts of intelligentsia history. Perhaps his most lasting impact on the field came in the form of two major articles published in the course of the early 1960s: "The Parties and the State: The Evolution of Political Attitudes in PostReform Russia," in Cyril E. Black, ed., The Transformation of Russian Society: Aspects of Social Change since 1861 (Harvard University Press, 1960); and "The Problem of Social Stability in Urban Russia, 1905-1917," which appeared in two issues of this journal in 1964 and 1965. Taken together, these articles presented a sweeping argument about the untenability of an autocratic social order riven by increasing polarization within Russian society-pitting educated urban elites against an increasingly "spontaneous" and militant working classalongside the irreconcilability of an emerging civil society and the autocratic state in their contention over the question of political power and prerogative in the post-1905 years. These works proposed significant revisions to prevailing Soviet and western interpretations, igniting an ongoing debate between "optimists" and "pessimists" over the viability of the imperial order. Other important scholarship included a long-running collaborative project on the history of the Menshevik movement, as well as his edited volume, The Politics of Rural Russia, 1905-1914 (Indiana University Press, 1979). For much of the 1980s and 1990s, he produced numerous joint studies on the Russian workers' movement from 1902 to 1917. Haimson continued to publish and write until shortly before his death, including the book Russia's Revolutionary Experience, 1905-1917: Two Essays (Columbia University Press, 2005).

Haimson's impact on the practice of Russian history derived equally from his role as graduate teacher. By his own estimate, he supervised roughly 100 dissertations on an impressive variety of topics spanning the Muscovite and the early Soviet eras. However varied their research interests, his students shared the experience of his demanding seminars,

Slavic Review 70, no. 3 (Fall 2011) 
his close attention to their developing dissertations, and his emphasis on archival sources and the importance of language as an entrée to protagonists' historical experience and motivations.

Finally, Haimson stood out for his abiding devotion to scholarly collaboration, evident in the Menshevik project, and his studies of the workers' movement. From his earliest visits to the USSR in the $1950 \mathrm{~s}$, he forged good working relations with Soviet colleagues, particularly in Leningrad/St. Petersburg, participating in and later organizing important international symposia on late imperial history. Closer to home, he presided over an informal monthly research seminar known to participants as the "Little Red Schoolhouse." This forum assembled senior scholars from the area, foreign visitors, and graduate students for extended discussion of current projects followed by the obligatory dinner at a local Chinese restaurant.

A brilliant and demanding, but also supportive, mentor and colleague, Haimson inspired strong reactions among students and fellow scholars alike. Whatever their differences, all would concede his keen psychological insight, mastery of the sources, and penchant for complex, yet compelling, arguments. Surviving Haimson are his beloved wife Natalia, three children from his first marriage-Joshua, Leonie, and Maud-and three grandchildren, Chloe, Jeremy, and Nathaniel.

DAVID MCDONALD

University of Wisconsin, Madison May 2011 